\title{
Seleenirikastuksen vaikutus siemenperunan fysiologiseen ikään
}

\author{
Marja Turakainen $^{1)}$, Helinä Hartikainen ${ }^{2)}$ ja Mervi Seppänen ${ }^{3)}$ \\ ${ }^{1)}$ Helsingin yliopisto, Soveltavan biologian laitos, PL 27, 00014 Helsingin yliopisto. Nykyinen \\ osoite Harjun oppimiskeskus, 48890 Ravijoki, turakainen@harjunopk.fi, \\ ${ }^{2)}$ Helsingin yliopisto, Soveltavan kemian ja mikrobiologian laitos, PL 27, 00014 Helsingin \\ yliopisto, helina.hartikainen@helsinki.fi \\ ${ }^{3)}$ Helsingin yliopisto, Soveltavan biologian laitos, PL 27, 00014 Helsingin yliopisto, \\ mervi.seppanen@helsinki.fi
}

\section{Tiivistelmä}

Suomen oloissa siemenperunan varastointijakso on pitkä ja sen aikana siemenperunan fysiologinen ikä lisääntyy eli se vanhenee hiljalleen. Samalla siemenperunan elinvoima alenee ja se tuottaa pienen sadon. Siksi elinvoiman säilyminen varastoinnin aikana mahdollisimman hyvänä on tärkeää.

Vaikka seleeniä ei pidetä kasveille välttämättömänä mikroravinteena, nousevien seleenilisäysten on osoitettu parantavan kasvien kasvua, sadon määrää ja laatua sekä lisäävän kasvisolujen antioksidatiivista puolustuskykyä. Kasvit tarvitsevat puolustusmekanismeja suojautuakseen sisäisten tai ulkoisten stressitekijöiden aiheuttamilta solujen hapetusvaurioilta. Vanheneminen on luonnollinen kasvien kehitysvaihe, jolloin solujen lipidien $\mathrm{mm}$. solukalvojen hapettuminen lisääntyy. Seleenin on havaittu hidastavan kasvien vanhenemista ja E-vitamiinipitoisuuden vähenemistä kasvin ikääntyessä. Seleeniä saaneiden kasvien on todettu myös säilyttävän pidempään tuoreutensa ja ravintoarvonsa.

Tutkimuksessa selvitettiin, voiko seleenilannoitus ylläpitää tai edistää siemenperunan elinvoiman säilymistä sekä hidastaa sen vanhenemista varastoinnin aikana. Seleenillä rikastetut siemenperunat tuotettiin edellisenä kasvukautena kasvihuonekokeessa nousevilla selenaattimäärillä $(0,0,0035,0,01,0,075$ ja $0,9 \mathrm{mg}$ seleeniä $\mathrm{kg}^{-1}$ kvartsihiekkaa) lannoitetuissa kasveissa. Niiden elinvoimaa tutkittiin selvittämällä varastointiajan vaikutusta itujen lukumäärään ja pituuteen ja laskemalla itämiskapasiteetti. Siemenperunoiden vanhenemista tutkittiin mittaamalla rasvahappojen hapettumistuotteen eli malondialdehydin (MDA) kertymistä varastoinnin aikana ja idätysjakson jälkeen. Seleenin vaikutusta siemenperunoiden satopotentiaaliin tutkittiin kasvihuonekokeissa määrittämällä niiden tuottamat sadot. Seleenipitoisuus määritettiin sekä siemenperunoista että seuraavan sadon mukuloista.

Pitkien itujen $(\geq 1 \mathrm{~cm})$ osuus ja itujen itämiskapasiteetti kasvoivat varastointiajan pidetessä kahdesta kahdeksaan kuukauteen. Korkeimmat seleenilisäykset $\left(0.075 \mathrm{ja} 0.9 \mathrm{mg} \mathrm{kg}^{-1}\right)$ paransivat kahdeksan kuukautta varastoitujen siemenperunoiden itämiskapasiteettia eli suurempi osa olemassa olevista iduista oli elinvoimaisia. Samanaikaisesti itujen putreskiinin pitoisuus oli korkein. Seleenillä ei ollut selvää vaikutusta siemenperunan vanhenemiseen. Korkein sato tuotettiin kuusi kuukautta varastoidulla siemenperunalla, riippumatta seleenilisäyksestä. Varastointiajan pidetessä kahdeksaan kuukauteen yhä korkeammat seleenilisäykset antoivat positiivisen sadonlisän.

Tulokset osoittavat, että korkeat seleenilisäykset edistävät siemenperunoiden itämispotentiaalia ja satopotentiaalia varastointiajan, mikäli varastointiaika on yli kuusi kuukautta. Seleenillä ei ole johdonmukaista siemenperunan vanhenemista hidastavaa vaikutusta siemenperunan ollessa sopivassa istutusiässä.

Asiasanat: elinvoima, fysiologinen ikä, peruna, seleeni, vanheneminen 


\section{Johdanto}

Tutkijat totesivat 1950-ja 1960-luvulla seleenin puutteen olevan perimmäinen syy useisiin eläinten aineenvaihduntasairauksiin, joihin ei oltu keksitty siihen mennessä mitään hoitoa. Myöhemmin osoitettiin, että maataloustuotteiden alhaisella seleenipitoisuudella on negatiivisia vaikutuksia myös ihmisten terveyteen, sillä se vähentää solujen kykyä puolustautua happiradikaalien haitallisilta vaikutuksilta. Alhaisen seleenin saannin on arveltu lisäävän sydän- ja verisuonisairauksien ja syövän riskiä. Koska Suomen maaperässä on niukasti biologisesti käyttökelpoista seleeniä, sitä on vuodesta 1985 lisätty lannoitteisiin kansanterveydellisistä syistä (Ekholm 1997 ja siinä olevat viitteet).

Vaikka seleeni on ihmisten ja eläinten terveydelle välttämätön alkuaine, kasvien ei ole kuitenkaan katsottu tarvitsevan sitä. Kasveja on pidetty lähinnä seleenin kierrättäjinä eläimiin ja ihmiseen. Helsingin yliopistossa tehdyissä pitkäaikaisissa kokeissa kuitenkin on havaittu, että seleeniannoituksella on positiivisia vaikutuksia myös kasvien kasvuun, sadon määrään ja niiden sadon laatuun (Hartikainen ym. 1997, Hartikainen ja Xue 1999, Xue ym. 2000, Xue ym. 2001). Lisäksi on havaittu, että pieni seleenilisäys hidastaa salaatin ja raiheinän (Xue ym. 2001) sekä soijapavun (Djanaguiraman ym. 2005) vanhenemista ja lisää niiden stressinkestävyyttä tehostamalla kasvien antioksidatiivista puolustusjärjestelmää. Kokeet ovat perustuneet oletukseen, että samalla tavalla kuin eläin- ja ihmissoluissa seleeni pystyy sopivalla pitoisuustasolla toimimaan myös kasveissa hapettumisvaurioilta suojaavana tekijänä eli auttamaan soluja puolustautumaan happiradikaalien aiheuttamia hapettumisvaurioita vastaan lisäämällä niiden antioksidatiivista kapasiteettia (Xue ym. 2000, Hartikainen ym. 2000, Pennanen ym. 2002). Hapettumisstressiä aiheuttavia happiradikaaleja syntyy kasvin normaalien elintoimintojen kuten yhteyttämisen ja hengityksen yhteydessä sekä ulkoisten stressitekijöiden kuten lyhytaaltoisen valon, kylmyyden tai hallan synnyttäminä.

Peruna on elävä, vesipitoinen kasvinosa, jossa varastoinnin tapahtuu aikana fysiologisia ja biokemiallisia muutoksia, jotka johtavat siemenperuna fysiologiseen vanhenemiseen ja sitä kautta mukulan elinvoiman ja satopotentiaalin alenemiseen. Varastoinnin kuluessa siemenperunan itämislepo ensin purkautuu ja se muuttuu yksi ituisesta moni-ituiseksi (Burton 1989, Struik \& Wiersema 1999). Suomessa siemenperunat joudutaan varastoimaan pitkään ja lisäksi lyhyen kasvukautemme vuoksi ne joudutaan esiidättämään eli vanhentamaan kasvurytmin nopeuttamiseksi.

Helsingin yliopistossa perunalla tehdyissä kokeissa seleenilannoitus nopeutti kasvien palautumista hallasta (Seppänen ym. 2003) sekä edisti tärkkelyksen ja sokereiden kertymistä perunan-nuoriin lehtiin, kasvun myöhemmässä vaiheessa myös rönsyihin (Turakainen ym. 2004a). Lisäksi seleeni vaikutti positiivisesti perunan sadonmuodostukseen, sillä seleenilannoitetut kasvit tuottivat suuremman sadon sekä vähemmän mutta keskikooltaan suurempia perunoita (Turakainen ym. 2004a). Varastoinnin aikana ei tapahtunut muutoksia mukuloiden seleenipitoisuudessa. Alhainen seleenipitoisuus vaikutti edullisesti perunan sisäiseen laatuun vähentämällä perunoiden raakatummumista, joka on etenkin perunatuotteita valmistavan teollisuuden ongelma (Turakainen ym. 2006).

Helsingin yliopistossa Soveltavan biologian laitoksella tehdyn tutkimuksen tavoitteena oli selvittää, voiko seleenin kasvien antioksidatiivistakapasiteettiä lisäävä vaikutus edistää myös siemenperunan elinvoiman säilymistä sekä hidastaa siemenperunan vanhenemista varastoinnin aikana.

\section{Aineisto ja menetelmät}

Seleenirikastetut siemenperunat (lajike Satu) tuotettiin edellisenä kasvukautena kasvihuoneessa kasveissa, jotka kasvatettiin nousevilla natriumselenaattilisäyksillä $(0,0,0035,0,01,0,075$ ja $0,9 \mathrm{mg}$ seleeniä $\mathrm{kg}^{-1}$ kvartsihiekkaa). Sato nostettiin 16 viikon kuluttua istutuksesta ja säilytettiin $4{ }^{\circ} \mathrm{C}$ :ssa.

Seleenin vaikutusta siemenperunoiden itämispotentiaaliin ja itujen elinvoimaan tutkittiin määrittämällä itujen pituus ja kasvun aloittaneiden itujen määrä suhteessa itujen kokonaismäärään eli itämiskapasiteetti. Kasvien seleenipitoisuus määritettiin pakastekuivatusta ja jauhetusta kasvimateriaalista atomiabsorptiospektrofotometrilla Kumpulaisen ym. (1983) ja Ekholmin (1997) kuvaamalla menetelmällä. Seleenin vaikutusta siemenperunan vanhenemiseen tutkittiin määrittämällä rasvahappojen hapettumistuotteiden, malondialdehydin (MDA) kertymistä (Kumar \& Knowless 1996). Sadosta tehtiin tilastolliset analyysit SAS-tilasto-ohjelmalla. P-arvoltaan $<0,05$ tulokset arvioitiin tilastollisesti merkitseviksi. 


\section{Tulokset ja tulosten tarkastelu}

\section{Seleenirikastuksen vaikutus siemenperuna itämiskapasiteettiin ja elinvoimaan}

Itujen itämiskapasiteetti lisääntyi varastointiajan edetessä (Kuva 1a, b). Korkeimmat seleenilisäykset ( $0,075 \mathrm{ja} 0,9 \mathrm{mg} \mathrm{kg}^{-1}$ maata) paransivat siemenperunoiden itämiskapasiteettia eli suurempi osa olemassa olevista iduista oli elinvoimaisia (Kuva b). Itämiskapasiteetin maksimi saavutettiin kahdeksan kuukauden varastoinnin jälkeen (Kuva 1b).

a)

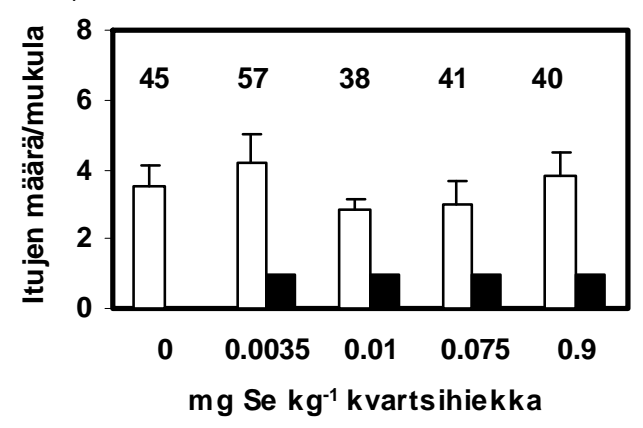

b)

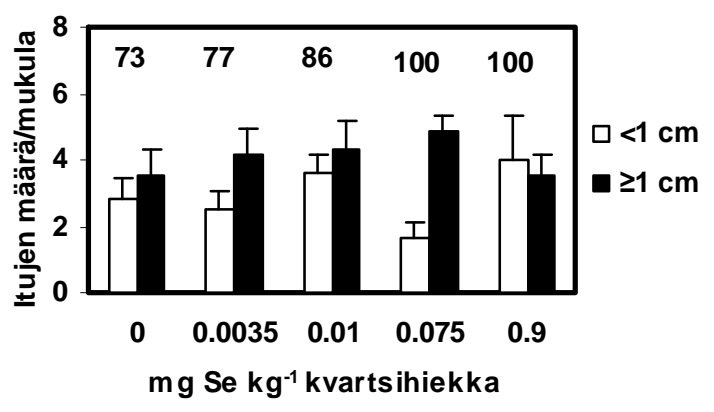

Kuva 1. Seleenillä rikastettujen siemenperunoiden itujen lukumäärä mukuloissa kahdessa eri pituusluokassa: $<1 \mathrm{~cm}$ ja $\geq 1 \mathrm{~cm}$. Varastointiajan pituus oli a) 2 ja b) 8 kuukautta. Pylväiden yläpuolella on ilmoitettu siemenperunoiden itämiskapasiteetti (\%).

\section{Seleenirikastuksen vaikutus siemenperunan vanhenemiseen}

Aikaisemmissa kokeissa on havaittu, että seleenin antioksidatiiviset vaikutukset hidastivat salaatin ja soijapavun lehtien vanhenemista tehostamalla kasvien puolustusjärjestelmää. Vaikutukset havaittiin nimenomaan kasvun loppua kohti eli ränsistyneissä kasveissa (Xue ym. 2001, Djanaguiraman 2005). Tässä kokeessa siemenperunoihin kertyi hieman MDA:a varastointiajan pidetessä kahdesta kahdeksaan kuukauteen seleenilannoituksesta riippumatta (tuloksia ei esitetty). Tämä osoittaa, että niissä tapahtui vanhenemiseen liittyviä muutoksia varastoinnin aikana. Idätettyjen perunoiden MDA-pitoisuus oli korkeampi kuin varastossa olleiden perunoihin, mikä osoittaa myös idätyksen nopeuttaneen siemenperunan vanhenemista (tuloksia ei esitetty). Seleenikäsittelyllä ei kuitenkaan saatu johdonmukaista vaikutusta siemenperunoiden MDA-pitoisuuteen. Vaikka muissa tutkimuksissa MDA:n kertymistä perunaan pidetään selvänä vanhenemista kuvaavan indikaattorina (Kumar \& Knowles 1996), tämän kokeen tulokset osoittivat, että MDA ei kuvaa siemenperunoiden vanhenemista niiden ollessa optimaalisessa fysiologisessa iässä. Tässä tutkimuksessa siemenperunat tuotettiin kasvihuoneessa kasvatetuissa kasveissa. Muissa kokeissa on havaittu, että kasvihuoneessa tuotetut perunat ovat fysiologisesti nuorempia verrattuna pellolla kasvaneisiin, vaikka sato on korjattu kasvuston osoittaessa tuleentumisen merkkejä. Suomessa kahdeksan kuukautta on normaali siemenperunan varastointiaika, mutta tässä kokeessa kasvihuoneessa tuotetuissa siemenperunoissa ei vielä havaittu vanhenemisen piirteitä.

\section{Seleenirikastuksen vaikutus siemenperunan satopotentiaaliin}

Korkein sato tuotettiin kuusi kuukautta varastoidulla siemenperunalla riippumatta seleenilisäyksestä (Taulukko 1). Kahdeksan kuukautta varastoidut siemenperunat tuottivat alhaisemman sadon, mikä viittaa siihen, että niiden optimaalinen ikä oli ohitetttu ja niiden satopotentiaali oli alentunut. Kuusi ja kahdeksan kuukautta varastoitujen siemenperunoiden tuottamien kasvien kasvuaika oli sama, mutta lämpötilasummakertymä oli n. 100 astetta suurempi kuusi kuukautta varastoidulla siemenperunalla. Tämä 
voi selittää osittain niiden tuottamat paremmat sadot, mutta ei poista seleenin positiivisia vaikutuksia sadon määrään.

Taulukko 1. Seleenillä rikastettujen siemenperunoiden tuottamat sadot (g/kasvi) ja perunoiden seleenipitoisuudet. Varastointiajat olivat kolme, kuusi ja kahdeksan kuukautta.

\begin{tabular}{clclc}
\hline $\begin{array}{c}\text { Varastointi } \\
\text {-aika } \\
\text { kuukautta }\end{array}$ & $\begin{array}{c}\text { Seleenilisäys } \\
\mathrm{mg} / \mathrm{kg} \text { maata }\end{array}$ & $\begin{array}{c}\text { Siemenperunan } \\
\text { seleenipitoisuus } \\
\mu \mathrm{g} / \mathrm{g} \mathrm{k} \text {-a }\end{array}$ & $\begin{array}{l}\text { Sato/kasvi }(\mathrm{g}) \\
\pm \text { keskivirhe } \\
\pm \text { ero kontrolliin } \\
\text { verrattuna }\end{array}$ & $\begin{array}{c}\text { Seuraavan sadon } \\
\text { seleenipitoisuus } \\
\mu \mathrm{g} / \mathrm{g} \mathrm{k} \text {-a }\end{array}$ \\
\hline 3 & 0 & 0,01 & $762 \pm 9$ & 0,00 \\
& 0,0035 & 0,12 & $740 \pm 15-3 \%$ & 0,01 \\
& 0,01 & 0,21 & $739 \pm 8-3 \%$ & 0,01 \\
& 0,075 & 1,38 & $733 \pm 18-4 \%$ & 0,03 \\
& 0,9 & 16,33 & $733 \pm 17-4 \%$ & 0,65 \\
\hline 6 & 0 & 0,01 & $1227 \pm 80$ & - \\
& 0,0035 & 0,08 & $1263 \pm 39+3 \%$ & - \\
& 0,01 & 0,18 & $1306 \pm 41+6 \%$ & - \\
& 0,075 & 1,42 & $1243 \pm 50+2 \%$ & - \\
\hline 8 & 0,9 & 16,25 & $1230 \pm 69 \pm 0 \%$ & - \\
& 0 & 0,01 & $1075 \pm 18$ & 0,00 \\
& 0,0035 & 0,10 & $1029 \pm 20-4 \%$ & 0,01 \\
& 0,01 & 0,22 & $1092 \pm 20+2 \%$ & 0,01 \\
& 0,075 & 1,37 & $1109 \pm 24+3 \%$ & 0,03 \\
\hline
\end{tabular}

\section{Perunoiden seleenipitoisuus}

Seleenilannoitus kohotti siemenperunoiden seleenipitoisuutta lannoitustasosta riippuen (Taulukko 1). Korkeimmilla seleenilannoitusmäärillä ( $0,075 \mathrm{ja} 0,9 \mathrm{mg}$ seleeniä/ $/ \mathrm{kg}$ maata) seuraavan sadon seleenipitoisuus oli noussut elintarvikkeissa tavoitellulle tasolle (Taulukko 1). Tulos osoittaa, että siemenperunaan kertynyt seleeni siirtyi uuteen perunasatoon.

\section{Johtopäätökset}

Tämän tutkimuksen tulokset osoittavat, että seleenirikastuksella on positiivisia vaikutuksia siemenperunan itujen elinvoimaan ja sen satopotentiaaliin, mikäli varastointiaika on yli kuusi kuukautta. Sitä vastoin seleenin antioksidatiiviset vaikutukset vanhenemiseen eivät mahdollisesti näy siemenperunoiden ollessa vielä fysiologisesti optimaalisessa iässä. Tämä viittaa siihen, että seleeni toimii kasvissa stressin vaikutuksia lieventävänä aineena.

\section{Kirjallisuus}

Burton, W. G. 1989. The Potato. 3. painos. New York. John Wley \& Sons, Inc.

Ekholm, P. 1997. Effects of selenium supplemented commercial fertilizers on food selenium contents and selenium intake in Finland. EKT-series 1047. Helsinki. ISBN 952-90-8392-0 (dissertation).

Hartikainen, H., Ekholm, P., Piironen, V., Xue, T., Koivu, T. \& Yli-Halla, M. 1997. Quality of ryegrass and lettuce yields as affected by selenium fertilization. Agric. and Food Sci. Finland 6: 381-387. 
Hartikainen, H. \& Xue, T. 1999. The promotive effect of selenium on plant growth as triggered by ultraviolet irradiation. J. Environ. Qual. 28: 1372-1375.

Hartikainen, H., Xue, T., \& Piironen, V. 2000. Selenium as anti-oxidant and pro-oxidant in ryegrass. Plant Soil 225 : 193-200.

Kumar, M.G.N. \& Knowles, R.N. 1993b. Changes in lipid peroxidation and lipolytic and free-radical scavenging enzyme activities during aging and sprouting of potato (Solanum tuberosum) seed-tubers. Plant Phys. 102: 115-124.

Kumpulainen, J., Raittila, A-M, Lehto, J. \& Koivistoinen, P. 1983. Electrothermal atomic absorption spectrometric determination of selenium in foods and diets. J. Assoc. Offic. Anal. Chem. 66: 1129-1135.

Palonen P. 1999. Relationship of seasonal changes in carbohydrates and cold hardiness in canes and buds of three raspberry cultivars. J. Am. Soc. Hortic. Sci. 124: 507-513.

Pennanen, A., Xue, T. \& Hartikainen, H. 2002. Protective role of selenium in plant subjected to severe UV irradiation stress. J. Appl. Bot. 76: 66-76

Seppänen, M. M. , Nissilä, O. \& Perälä, S. 2001. Agric. and Food Sci. Finland 10: 153-163.

Seppänen, M. M. \& Coleman, G. D. 2003. Characterization of genotypic variation in stress gene expression and photosynthetic parameters in potato. Plant Cell Environ. 26: 401-410.

Seppänen, M., Turakainen M. \& Hartikainen, H. 2003. Selenium effects on oxidative stress in potato. Plant Sci. 165: 311-319.

Struik, P.C. \& Wiersema, S.G. 1999. Seed Potato Technology. Wageningen Pers, Wagenning, Netherlands.

Terry, N. \& Zayed, A.M. 1998. Phytoremediation of selenium. In: Frankenberger WT Jr, and Engberg RA (Eds) Environmental chemistry of selenium. Marcel Dekker Inc, New York, pp. 633-655.

Turakainen, M., Hartikainen, H. \& Seppänen, M. M. 2004a. Effects of selenium treatments on potato (Solanum tuberosum L.) growth and concentrations of soluble sugars and starch. Agric. Food Chem. 52: 5378-5382.

Turakainen, M., Väänänen, T., Anttila, K., Ollilainen, V, Hartikainen, H. \& Seppänen, M. M. 2004b. Effect of selenate supplementation on glycoalkaloid content of potato (Solanum tuberosum L.). J. Agric. Food Chem. 52: 71397143.

Turakainen, M., Hartikainen, H. Ekholm, P. \& Seppänen, M. M. 2006. Distribution of selenium in different biochemical fractions and raw darkening degree of potato (Solanum tuberosum L.) tubers supplemented with selenate. J. Agric. Food Chem. 54: 8617-8622.

Turakainen, M., Hartikainen, H., Sarjala, T. \& Seppänen, M.M. 2006. Physiological age of selenium enriched seed potato tubers. Lähetetty käsikirjoitus 6/2007 Agric. and Food Sci. Finland.

Xue, T. \& Hartikainen, H. 2000. Association of antioxidative enzymes with the synergistic effect of selenium and UV irradiation enhancing plant growth. Agric. Food Sci. Finland 9: 177-186.

Xue T., Hartikainen, H. and Piironen, V. 2001. Antioxidative and growth-promoting effect of selenium on senescing lettuce. Plant Soil 237: 55-61. 